\title{
A webometriáról - a 2015. évi Derek John de Solla Price-emlékérem odaítélése alkalmából
}

\author{
Schubert András \\ MTA Könyvtár és Információs Központ, Tudománypolitikai és Tudományelemzési Osztály, Budapest
}

\begin{abstract}
A tudománymetria legjelentősebb szakmai elismerését, a Derek John de Solla Price-emlékérmet 2015-ben az angol Mike Thelwall nyerte el. Thelwall a webometria meghatározó személyisége, a tudományos kutatás internetes jelenlétét vizsgálja kvantitatív módszerekkel. Ebben a cikkben a webometria kialakulását, helyzetét és fejlődési irányait tekintjük át röviden. Orv. Hetil., 2015, 156(36), 1472-1474.
\end{abstract}

Kulcsszavak: tudománymetria, webometria, altmetria

\section{Webometrics - on the occasion of the awarding of the Derek John de Solla Price Medal, 2015}

The most significant recognition in scientometrics, the Derek John de Solla Price Medal was awarded in 2015 to Mike Thelwall. Thelwall is a dominant personality in webometrics studying the internet presence of scientific research with quantitative methods. In this paper the emergence, standing and directions of webometrics are briefly reviewed

Keywords: scientometrics, webometrics, altmetrics

Schubert, A. [Webometrics - on the occasion of the awarding of the Derek John de Solla Price Medal, 2015]. Orv. Hetil., 2015, 156(36), 1472-1474.

(Beérkezett: 2015. június 2.; elfogadva: 2015. június 25.)

Derek John de Solla Price, fizikus, tudományfilozófus és információkutató - aki munkássága, mindenekelőtt „Kis tudomány - Nagy tudomány" címü könyve [1] alapján méltán nevezhetô a tudománymetria atyjának -, 1983ban hunyt el. A Scientometrics címü folyóirat alapító föszerkesztője, Braun Tibor, még abban az évben elhatározta, hogy Price emlékét egy olyan éremmel is megőrzi, amelyet a tudomány kvantitatív vizsgálatában kiemelkedő eredményeket elért kutatóknak ítél oda bizonyos rendszerességgel a folyóirat szerkesztőbizottsága, illetve az általuk kijelölt testület.

Az első Derek John de Solla Price-emlékérmet 1984ben Eugene Garfield, az Institute for Scientific Information alapítója és akkori tulajdonosa, a Science Citation Index adatbázis kiötlője és megvalósítója nyerte el. Eddig összesen 27 kutató részesült ebben a megtisztelő kitüntetésben (1. táblázat). 1993 óta az érmet minden páratlan évben ítélik oda, és az International Society for Scientometrics and Informetrics (ISSI) kétévenként megrendezett konferenciáján adják át a díjazottnak. Az idei konferenciát június 29-július 4. között tartották Isztambulban. Az idei év kitüntetettje, Mike Thelwall, a Wolverhamptoni Egyetem professzora személyében először nyerte el a díjat egy olyan kutató, aki a fó kutatási területeként nem a hagyományos értelemben vett (akár nyomtatott, akár online formában megjelent) tudományos szakirodalmat, hanem a tudományos kutatás résztvevőinek internetes jelenlétét elemzi.

Ezt a területet a Price-emlékérem egyik korábbi kitüntetettje, a dán Peter Ingwersen nevezte el webometriának egy 1997-es cikkében [2]. Ez a cikk mindmáig a webometria legidézettebb múve (e cikk megírásáig a Thomson-Reuters Web of Knowledge szerint 203 idézetet kapott). A cikk elején a szerzők a webometriát úgy 
\begin{tabular}{l|l} 
1. táblázat & $\begin{array}{l}\text { A Derek John de Solla Price-emlékérem kitüntetettjei } 1984- \\
2015 \text { között }\end{array}$
\end{tabular}

\begin{tabular}{|c|c|}
\hline 1984 & Garfield, Eugene (Amerikai Egyesült Államok) \\
\hline 1985 & Moravcsik, Michael J. (Amerikai Egyesült Államok) \\
\hline 1986 & Braun Tibor (Magyarország) \\
\hline \multirow[t]{2}{*}{1987} & Nalimov, Vasily V. (Szovjetunió) \\
\hline & Small, Henry (Amerikai Egyesült Államok) \\
\hline 1988 & Narin, Francis (Amerikai Egyesült Államok) \\
\hline \multirow[t]{2}{*}{1989} & Brookes, Bertram C. (Egyesült Királyság) \\
\hline & Vlachy, Jan (Csehszlovákia) \\
\hline 1993 & Schubert András (Magyarország) \\
\hline \multirow[t]{2}{*}{1995} & Van Raan, Anthony F. J. (Hollandia) \\
\hline & Robert K. Merton (Amerikai Egyesült Államok) \\
\hline \multirow[t]{3}{*}{1997} & Irvine, John (Egyesült Királyság) \\
\hline & Martin, Ben (Egyesült Királyság) \\
\hline & Griffith, Belver C. (Amerikai Egyesült Államok) \\
\hline \multirow[t]{2}{*}{1999} & Glänzel, Wolfgang (Magyarország/Belgium) \\
\hline & Moed, Henk F. (Hollandia) \\
\hline \multirow[t]{2}{*}{2001} & Rousseau, Ronald (Belgium) \\
\hline & Egghe, Leo (Belgium) \\
\hline 2003 & Leydesdorff, Loet (Hollandia) \\
\hline \multirow[t]{2}{*}{2005} & Ingwersen, Peter (Dánia) \\
\hline & White, Howard D. (Amerikai Egyesült Államok) \\
\hline 2007 & Katherine W. McCain (Amerikai Egyesült Államok) \\
\hline \multirow[t]{2}{*}{2009} & Vinkler Péter (Magyarország) \\
\hline & Zitt, Michel (Franciaország) \\
\hline 2011 & Persson, Olle (Svédország) \\
\hline 2013 & Cronin, Blaise (Amerikai Egyesült Államok) \\
\hline 2015 & Thelwall, Mike (Egyesült Királyság) \\
\hline
\end{tabular}

definiálják, mint „a hálózati kommunikáció informetriai vagy más kvantitatív mérőszámokat felhasználó kutatása”. Ez a definíció nyilvánvalóan túlságosan tág, és a cikk további részében maguk a szerzők is egy sokkal szúkebb értelemben, kizárólag a tudományos kommunikáció vizsgálatára használják. Itt jegyezhetjük meg, hogy az információtudomány és -technológia területén webmetria (angolul web metrics vagy web analysis) néven foglalkoznak az internet hálózatának általánosan vett kvantitatív analízisével, amelynek olyan területeken van kiemelkedő fontossága, mint például az internetes keresőrendszerek optimalizálása (gondoljunk például a Google PageRank algoritmusára), vagy a kereskedelmi honlapok eredményes múköóesének elősegítése.

Ingwersen alapcikkével egy időben Madridban Isidro Aguillo, a Spanyol Nemzeti Kutatási Tanács (CSIC) munkatársa indított el egy hasonló témájú kezdeményezést. Megalapította a Cybermetrics címú online folyóiratot [3], amely az internet tudományos célú felhasználásának elemzését tûzte ki céljául. A folyóirat 1997 óta

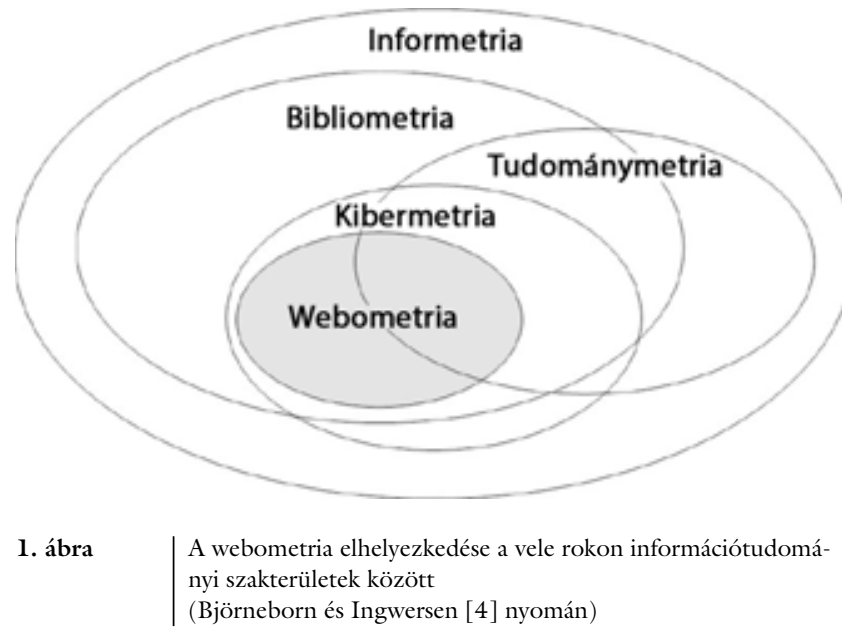

rendszertelen idóközönként közöl a témába vágó cikkeket; a legutóbbi cikk 2013-ban jelent meg.

A kibermetria kifejezés mindazonáltal viszonylag kevéssé terjedt el, részben talán azért is, mert CyberMetrics Corporation néven már hosszú ideje múködik az arizonai Phoenixben egy nemzetközileg ismert szoftvercég. Björneborn és Ingwersen [4] mindenesetre a kibermetriát is belefoglalta abba a „rendszertanba”, amellyel a webometria helyét próbálták meghatározni a vele rokon információtudományi szakterületek között ( 1 . ábra). Véleményem szerint ez a rendszertan ma már semmiképpen nem állja meg a helyét, és a későbbiekben megpróbálok majd egy módosított változatot felvázolni.

A kibermetria és a webometria egybeolvadásának egyik jele, hogy Aguillo és az általa vezetett Kibermetriai Laboratórium jelenlegi egyik legjelentősebb projektje a Világ Egyetemeinek Webometriai Rangsora [5] nevet viseli.

Thelwall a 2000-es évek legelején kapcsolódott be a webometriai kutatásokba, először a szintén Ingwersen által alkotott „webimpaktfaktor” tanulmányozásán keresztül $[6,7]$. Ezzel a mutatószámmal a folyóiratok impaktfaktora mintájára kíséreltek meg a weblapok értékelésére alkalmas mérőszámot létrehozni. Thelwallnak nagy szerepe volt abban, hogy a kezdeti fogalmi bizonytalanságok után a webometria önálló arculattal rendelkező kutatási területté válhatott. Szerepét azzal is nyomatékosította, hogy az elmúlt másfél évtizedben ebben a témában megjelent cikkek közel egynegyedének szerzője, illetve társszerzője volt.

A webometria és a webimpaktfaktor témájában megjelent cikkek időgörbéje a 2. ábrán látható. Az ábrán feltüntetett exponenciális növekedési görbe körülbelül 5 éves kétszereződési időt mutat (a 2015-ös év természetesen csonka). Ez rendkívül dinamikus fejlődésre utal.

A webometriának önálló folyóirata nem lévén, a cikkek a tudomány- és informetria, valamint az információtudomány szakfolyóirataiban jelennek meg. A cikkek közel egynegyedét a Scientometrics közölte, ezt követve a sorrend: Journal of the American Society for Information 


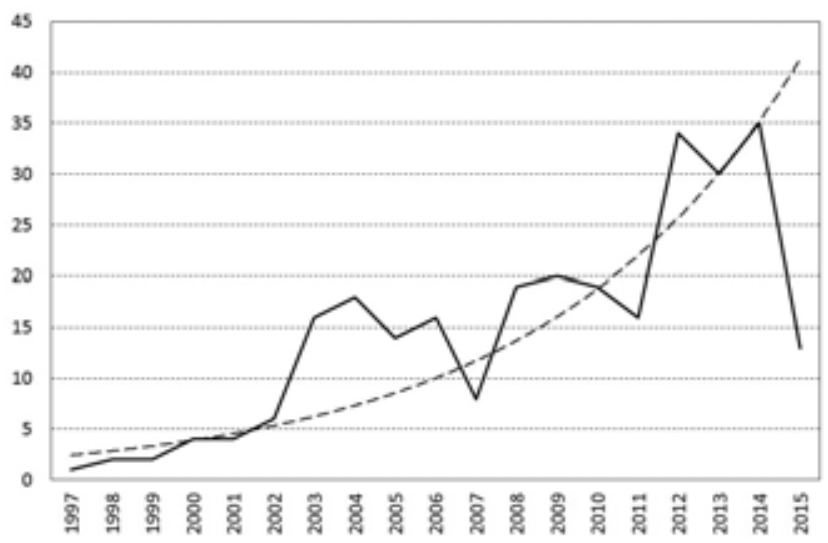

2. ábra

A webometria és a webimpaktfaktor témájában megjelent cikkek időgörbéje (Forrás: Thomson-Reuters Web of Knowledge)

Science and Technology, Journal of Information Science, Journal of Informetrics, ASLIB Proceedings, Journal of Documentation. Ez a hat folyóirat tartalmazza a webometria irodalmának több mint a felét.

2010-ben négy fiatal kutató egy kiáltványt tett közzé [8], amelyben körvonalazták az általuk altmetriának elnevezett terület célkitüzéseit. A webometriában szokásos források mellett elképzeléseik szerint a tudománnyal kapcsolatos kommunikáció legszélesebb spektrumát bele kell vonni a kutatás értékelésébe. Ebbe a körbe tartoznak egyebek között:

- a közösségi média különféle formái, mint például a Twitter és a Facebook;

- az online hivatkozási rendszerek (például CiteULike, Zotero és Mendeley);

- a kollaboratív enciklopédiák (Wikipedia);

- a tudományos és ismeretterjesztő blogok;

- a tudomány közösségi hálózatai (például ResearchGate vagy Academia.edu);

- konferenciaszervező weboldalak, mint amilyen a Lanyrd.com.

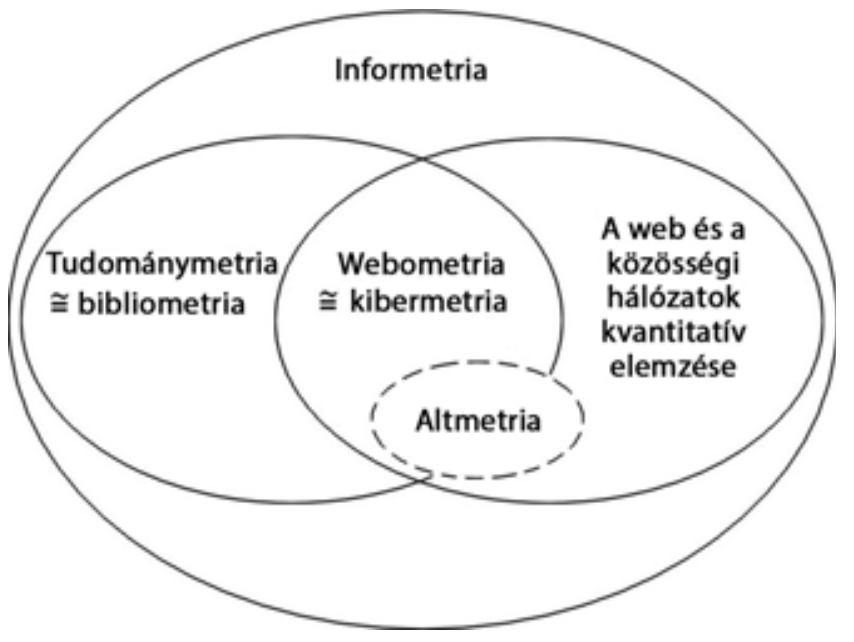

3. ábra

| A tudománymetria és a vele rokon területek elhelyezkedése
Az altmetria, mint mozgalom, tartalmi és személyi kapcsolatok révén összefonódik a nyílt hozzáférés („open access”) mozgalommal. Nem véletlen tehát, hogy az altmetria eredményeinek egyik fó gyưjtőhelye a nyílt hozzáférésű szakirodalom egyik vezérhajója: a PLOS ONE [9].

Mindezekkel a legújabb fejleményekkel együtt, a tudománymetria és rokon területei gyakorlatát (és nem feltétlenül a mégoly jeles szakértők tételes kinyilatkoztatásait) tekintve az egyes területeknek a 3. ábra szerinti elrendezését tartom a legelfogadhatóbbnak.

Az informetria a tudomány, valamint a web és a közösségi hálózatokon kívül más információs csatornák kvantitatív elemzésével is foglalkozik. (Példaként hadd említsem szerény próbálkozásomat a dzsesszdiszkometria területén [10].) A tudománymetria és a bibliometria, valamint a webometria és a kibermetria lényegében szinonimaként használatosak. Azt csak a jövő dönti el, hogy az altmetria megmarad-e a webometria (és ezzel a tudománymetria) jelenlegi határain belül, illetve, hogy ezek a határok esetleg rugalmasan magukba fogják-e foglalni az altmetria fejlődési irányait.

Anyagi támogatás: A szerző köszöni az FP7-SSH-2013-2 \#613202 (IMPACT-EV) projekt támogatását.

A cikk végleges változatát a szerző elolvasta és jóváhagyta.

Érdekeltségek: A szerzőnek nincsenek érdekeltségei.

\section{Irodalom}

[1] Price, D. J. de Solla: Little science, big science. Columbia University Press, New York, 1963. [Hungarian edition: Price, D. de Solla: Kis tudomány - Nagy tudomány. Akadémiai Kiadó, Budapest, 1979.]

[2] Almind, T. C., Ingwersen, P.: Informetric analyses on the World Wide Web: Methodological approaches to 'webometrics'. J. Document., 1997, 53(4), 404-426.

[3] CYBERmetrics, Int J Scientometr, Inform Bibliometrs. http:// cybermetrics.cindoc.csic.es

[4] Björneborn, L., Ingwersen, P.: Toward a basic framework for webometrics. J. Am. Soc. Inform. Sci. Technol., 2004, 55(14), 1216-1227.

[5] Webometrics Ranking of World Universities. http://www.webometrics.info

[6] Ingwersen, P.: The calculation of Web impact factors. J. Document., 1998, 54(2), 236-243.

[7] Thelwall, M.: Web impact factors and search engine coverage. J. Document., 2000, 56(2), 185-189.

[8] Priem, J., Taraborelli, D., Groth, P., et al.: Altmetrics: A manifesto, 26 October 2010. http://altmetrics.org/manifesto

[9] Altmetrics Collection, 2012, PLOS Collections. http://www. ploscollections.org/altmetrics

[10] Schubert, A.: Jazz discometrics - A network approach. J. Informetrics, 2012, 6(4), 480-484. 